\title{
Developing an Interactive Social Media Based Learning Environment
}

\author{
Joseph T. Chao \\ Bowling Green State University \\ Bowling Green, Ohio, USA
}

jchao@bgsu.edu

\author{
Kevin R. Parker \\ Idaho State University \\ Pocatello, Idaho, USA \\ parkerkr@isu.edu
}

\section{Anthony Fontana \\ Bowling Green State University, Bowling Green, Ohio, USA}

\section{afontana@bgsu.edu}

\begin{abstract}
The interactive social media based learning environment is a software system that provides a social media classroom experience for interactive learning. Students $\log$ in with a mobile device, such as an iPad or a laptop, and participate in a classroom environment in which they can view lecture slides, "chat" on-line with other users during the lecture, tweet to their followers, post items to their Facebook page, and collaborate with each other on topics. Within the learning environment, the student may also ask, rate, and answer questions on-line. The instructor has the capability of synchronizing lecture slides on the student's mobile devices as well as administering quizzes throughout the lecture and displaying visual results for the quizzes.
\end{abstract}

Keywords: Pedagogy, agile software development, interactive learning, collaborative learning, social media.

\section{Introduction}

With the advance in Web 2.0 technologies and the popularity of social networking on the web, educators have started to see a radical evolution in education. Some of the Web 2.0 building blocks, such as blogs and wikis, have been widespread throughout grades K-12 as well as higher education institutions in recent years (Parker \& Chao, 2007) while educational uses of social networking tools like Facebook and Twitter are beginning to appear. Educators may soon reach a point at which it is difficult to imagine education without them (Hargadon, 2009).

Material published as part of this publication, either on-line or in print, is copyrighted by the Informing Science Institute. Permission to make digital or paper copy of part or all of these works for personal or classroom use is granted without fee provided that the copies are not made or distributed for profit or commercial advantage AND that copies 1) bear this notice in full and 2) give the full citation on the first page. It is permissible to abstract these works so long as credit is given. To copy in all other cases or to republish or to post on a server or to redistribute to lists requires specific permission and payment of a fee. Contact Publisher@InformingScience.org to request redistribution permission.
This paper describes the development and current features of an interactive social media based learning environment. This web-based tool embraces social media and other Web 2.0 technologies to provide a new experience for interactive learning, and is designed to encourage student interaction, engagement, and participation in a dynamic lecture classroom. The tool allows students to view and navigate lecture slide- 
shows, as well as participate in quizzes, take part in a classroom chat room, ask questions, and take notes. The tool was designed and implemented as a student team project in a software development course using agile development techniques to make possible a new pedagogical approach.

Social media has been defined as "a group of Internet-based applications that build on the ideological and technological foundations of Web 2.0, which allows the creation and exchange of user-generated content" (Kaplan \& Haenlein, 2010, p. 61). Because of the importance of social media to this study, the paper begins with a brief overview of the rise of social media tools, transitions to a discussion of the interactive learning environment, progresses to a discussion of the features and technology of the system, describes the development process, and concludes with a discussion of future development and conclusions.

\section{The Rise of Social Media}

In a matter of a few short years, innovations in social media technologies have multiplied on a scale never before seen, revolutionizing not just the way in which we communicate, but also how we interact with others (Weisgerber \& Butler, 2010). The ascent of social software provides new avenues and new opportunities for increased participation and collaboration (Parker \& Chao, 2008). The participatory web, including social networking sites such as Facebook and contentsharing sites such as YouTube and Flickr, allow individuals to establish or maintain connections with others, establish their social networks, and share information in the form of wikis, blogs, tweets, podcasts, video, RSS feeds, and more (McCarthy, 2010; Weisgerber, 2008). Facebook currently claims 500 million active users sharing more than 30 billion pieces of content each month in the form of web links, news stories, blog posts, notes, photo albums, etc. (Facebook Statistics, 2010). Twitter, a social networking and microblogging service, is averaging well over 90 million tweets per day (Rao, 2010). People are flocking to the Internet in order to upload pictures, share videos, tell stories, and simply interact with others (Weisgerber \& Butler, 2010).

The changes brought about by new social media technologies have become so widespread and inculcated into our culture that it is futile to try to stop their influence at the classroom door. However, they have the potential to complement, enhance, and add new collaborative dimensions to the classroom (Parker \& Chao, 2007).

In order to most effectively engage students, it is essential to understand not only their attitudes toward their academic life, but also toward their social life (McCarthy, 2010). Many of today's younger students can be thought of as "digital natives", a term coined by Prensky (2001) to describe individuals who have known nothing but a digital environment since birth, surrounded by and using cell phones, computers, videogames, digital music players, and all the "necessities" of the digital age. In many cases this digital culture has influenced student skills and preferences in a number of key areas related to education (McCarthy, 2010). These students prefer receiving information quickly and are adept at processing that information rapidly, they prefer multi-tasking and non-linear access to information, they have a low tolerance for lectures and prefer active rather than passive learning, and they rely heavily on social media for social and professional interactions and accessing information (McCarthy, 2010).

Many students prefer that familiar technologies be used as part of their education, not only because they have mastered these tools and use them on a daily basis, but also because they recognize how useful these tools can be (Prensky, 2007). Weisgerber and Butler (2010, Editors' Introduction section, para.2) note:

Although critics may see the constant connectedness offered by these new participatory technologies as a distraction hindering effective learning and resist the idea of incorporating such technologies into our classrooms, it is difficult to deny that blogs, microblogs, wikis, and social networks are quickly transforming, if 
not the classroom itself, then at least the learning environment our students operate in.

Social media can also assist international students to develop a sense of belonging in the academic community, specifically in building cross-cultural connections with local students (McCarthy, 2008). Although peers in the academic community often play a critical role in acclimating international students (Krause et al., 2003), language barriers and students' inhibitions can discourage such interaction, even on a basic level. Some forms of computer-mediated communication, such as social media, can help international students overcome these barriers to interaction (Bargh, McKenna, \& Fitzsimons, 2002).

\section{The Interactive Learning Environment}

At our university, instructors have been embracing and looking for innovative ways of using social media in the classroom. Sponsored by the university's Information Technology Services, the author led students enrolled in a software development class in designing and implementing a web-based social media interactive learning environment. The learning environment aims to create an impactful social engagement within a lecture-based classroom.

The use of the interactive learning environment begins with an instructor uploading a set of lecture slides and setting up an interactive learning session. This task may include adding quiz questions and the lecture session preferences prior to entering the classroom. The instructor has an expanded user interface that provides access to these administrative functions such as uploading slideshows, creating quizzes, and enabling or disabling interactive features. The ability to enable or disable interactive features gives the instructor control over the degree to which social media is used. For example, the instructor can enable or disable a feature that allows students to chat with each other during the classroom lecture and collaborate on various topics. Further, the instructor has the option of disabling access to Twitter and Facebook, depending on his/her pedagogical approach.

The following scenario describes student interaction with the interactive learning environment:

A student attends a lecture-based course such as Art History 101 equipped with an iPad or other mobile device, such as a tablet PC, a laptop computer, or a smart phone. On the screen in the front of the classroom is a short URL web link for the day's classroom module. The student types that URL into the browser on their portable device. A touch interface web application opens up (see Figure 1) and the student is asked to log in using either the university ID or other credentials such as a registered Facebook or Twitter ID. Once they log in, they are registered to use the system and their attendance is noted. If students do not log in using their university ID, Facebook, or Twitter credentials their user experience is limited to a slideshow view only.

On their screen they see a lecture slide window with buttons on the side of the screen that allows them to interact with others in and out of the classroom. The instructor begins the lecture by opening the same link and clicking on the slideshow button. Initially, both the student and teacher view the same screen. The instructor has the option of either synchronizing the student view with the slides projected on the screen or allowing students to navigate freely through the presentation.

The learning environment allows the students to collaboratively create and even share notes. As the instructor begins the lecture, the students can take notes by clicking the button with the Notes icon. This causes a note-taking window to pop 
up, which allows students to access their preferred method of taking notes, including the university wiki, a blank Google Docs document, or a plain text editing feature that can be stored and later emailed or moved to another computer. Each of the note-taking approaches provides a WYSIWYG editing system. At the end of any note-taking session, the student can choose to share their notes, and they are then made available on the university's Learning Management System.

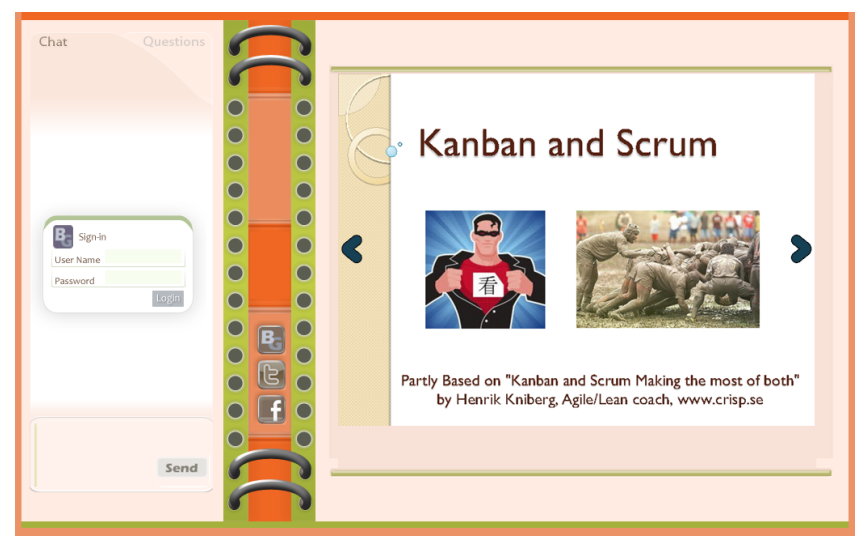

Figure 1: Login screen and Lecture Interface

As the lecture progresses, a student may miss something or simply be unclear on a certain point. The learning environment allows the students to easily ask, rate, and answer questions that they may have. If the student prefers to seek clarification from classmates rather than addressing the instructor, he or she can click the button with the Chat icon to open a chat window on the left side of the interface. The student can type a question for fellow students into the chat box and within a few seconds other students can respond. Their names are shown by the ID with which they have chosen to represent themselves. During the lecture, the student may also have more detailed questions for the instructor. In that case, the student clicks the button marked by a question mark that appears next to the slideshow window. When the student touches and holds the question button, the system displays a text box in which the student can type their question. When the question is submitted, it is immediately added to the classroom question window, queued behind any other student questions, and highlighted. The instructor's screen also displays a notification that a student asked a question. This alerts the instructor to look at the question window to see what questions have been posted and if any of them have been answered by other students. A student has the option of canceling a question if another student answers it before the instructor. Students may also vote on questions that have been submitted if they also want that question answered. This makes it possible for questions to be ranked to allow the instructor to make the best use of lecture time.

The instructor is able to administer quizzes throughout the lecture by associating questions with certain slides in the slideshow. When the lecture reaches a point at which the quiz question is scheduled to appear, a new window appears on the student interface and all other windows are obscured. The new window displays the quiz question(s) the instructor planned for this point as well as either a text box in which to answer the questions or multiple choice radio buttons from which to choose. Once the student answers the question and clicks the submit 
button, the question screen slides away and the original windows resume their previous appearance.

The instructor is also able to generate visual representations of how the students performed on the quizzes and at the conclusion of the lecture the student is able to access his or her success on the quiz questions by clicking on the Assessment Data button. The student is presented with their score and/or a graph that shows how they scored against other students, although they are unable to view other students' scores. At this point they can choose to share their score with the rest of the class by clicking the share button. This also automatically enrolls the student in the classroom scoring system. Students may also choose to post their scores to Facebook or Twitter as an update that reads "I just scored __ out of __ on a quiz in Professor XYZ's Art History course!" No scores are posted unless the student opts to do so.

The classroom scoring system is a way for the instructor to award badges, assign ranks, and assess classroom participation. Student engagement is tracked beyond merely recording quiz scores; the system also tracks the number of words typed in the chat room or in the notes, or how many questions the student asked. Students are ranked on these categories in addition to quiz scores, and may share their results on Facebook and Twitter. However, individual student scores are not posted by the system automatically. The decision of posting or sharing their own accomplishments is left to each student's discretion. In addition, a student might be awarded a badge the first time they get all questions on a quiz correct, and they can post that badge to their Facebook with an update. Another student may be ranked the number one note taker in the class based on the number of words they typed. They can post these acknowledgements publicly via Twitter.

\section{Features and Technology}

The learning environment is a web-based system that is designed to be accessed using laptops, iPads, and other mobile devices such as tablet PCs or smart phones. To avoid the complication of using commercial tools, the entire system was built using open source technologies, and utilizing open APIs (Application Programming Interface) to communicate with existing platforms such as Facebook, Twitter, Wiki, and Google Docs. The technologies used include the LAMP stack (Linux, Apache, MySQL, and PHP), JavaScript, XHTML, CSS, the Zend Framework, and several other open source tools and libraries.

Using the narratives given in the previous section, user stories were developed. A user story is an agile software development technique that captures customer requirements without a formalized requirements document (Beck \& Fowler, 2000). A user story consists of system requirements written in non-technical language that captures what the user wants. At the time of writing this paper, the user stories listed in Table 1 (for instructor users) and Table 2 (for students) have been completed. 
Table 1: User Stories for Instructor Users

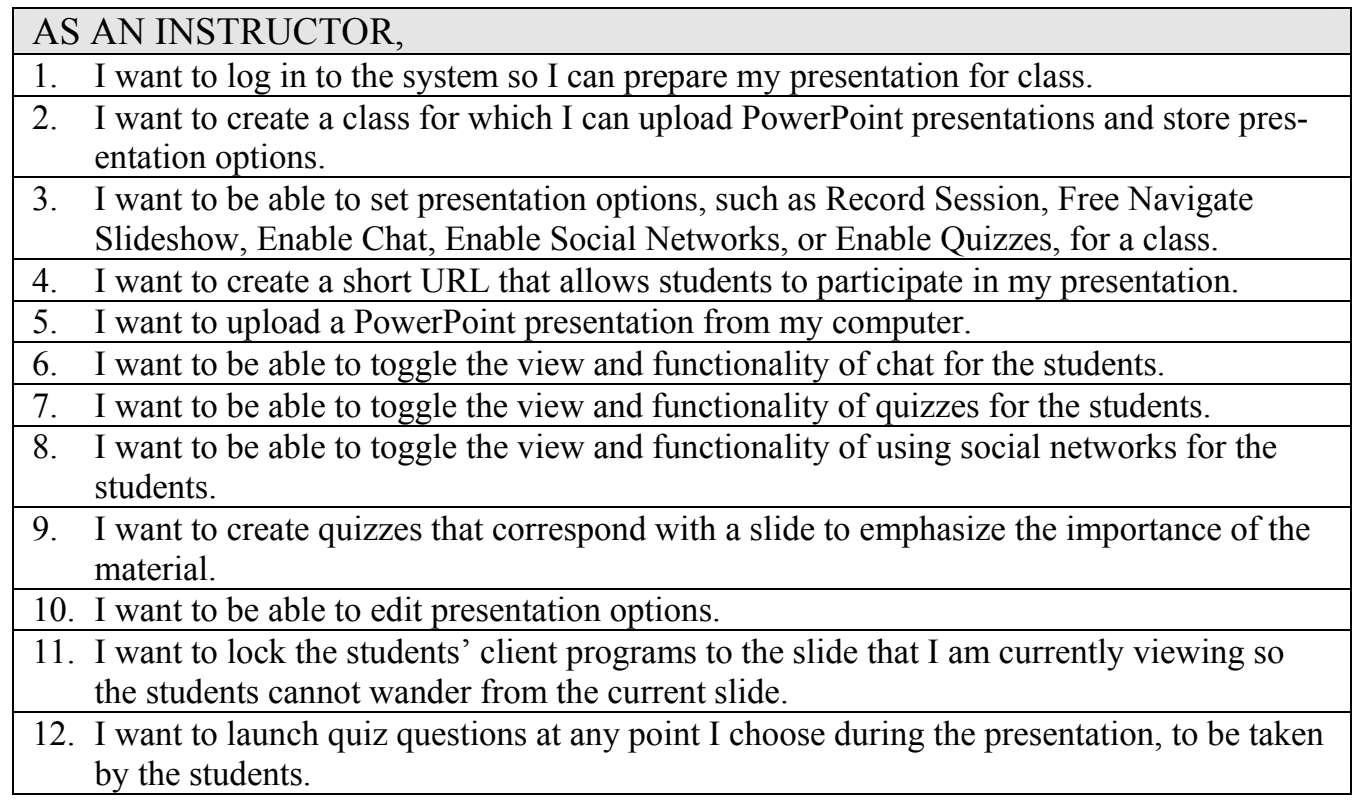

Table 2: User Stories for Student Users

\begin{tabular}{|cl|}
\hline \multicolumn{2}{|l|}{ AS A STUDENT, } \\
\hline 1. & I will be able to login to the class page with my university username and password. \\
\hline 2. & I will be able to access my profile and enter my Facebook username and password for later \\
& use to post awards. \\
\hline 3. & I will be able to view the login component for the Chat. \\
\hline 4. & I will be able to view the chat room. \\
\hline 5. & I will be able to participate in the chat room to interact with other students. \\
\hline 6. & I can win awards through participation in the class using the application. \\
\hline 7. & I can post the awards I achieved to my Facebook. \\
\hline 8. & I can post the awards I achieved to my Twitter page. \\
\hline 9. & I will be able to access my profile to enter my Twitter username and password for later use to \\
post awards.
\end{tabular}


Several aspects of the Interactive Learning Environment were expressly provided to achieve the participatory features of social media and Web 2.0. These are incorporated throughout the learning environment, including the question submission feature, the note-taking feature, and the scoring feature.

The question submission feature has many social media aspects. Merely posting a question is itself a participatory event. Posting is one of the most ubiquitous events on participatory sites. This allows students to influence the content of the lecture. The question submission feature also allows students to chat about questions that other students have posed. Students can use on-line chat to communicate by sending text messages to each other in real-time. Students can also vote on each question, thereby rating its importance and increasing the probability that it will be answered by the teacher or another student. Voting is an integral feature of social networks like Digg, and these votes are used to rank and filter high quality content. In our learning environment these rankings are used to increase the importance of student questions if multiple students share those questions. Students can also tag questions to annotate and categorize content, providing a system of classification also known as folksonomy. This allows the teacher to later determine which parts of the classroom discussion require more coverage.

The note taking feature also lends itself to social media. As pointed out, notes can be recorded in a wiki or using Google Docs. Wikis are one of the oldest examples of social media and Web 2.0, and are designed to encourage collaboration. Google Docs, which touts itself as "Social Media for Working \& Learning", is also designed to allow collaboration.

The scoring feature provides the omnipresent Facebook and Twitter icons/links so students can post their score to Facebook or Twitter as an update. Students are also awarded badges, another social media phenomenon, for exemplary work. Badges are used not only for recognition and acknowledgement, but also to allow others to vote on the achievement as well as share it. Badges consist of an image and an HTML link to a student's profile, and can help others find them online and follow their activity.

These are just some of the social media features that are possible in this interactive learning environment. Additional features will be considered as the system matures.

\section{Development Process}

The system was developed by students in a project-based software development course in the Department of Computer Science. A total of 18 students, mostly seniors and first year graduate students, worked together as a team on this project. Since the original scope of the project was too large for a class of students to complete in a short semester and the requirements were not well specified, an iterative and incremental model was used to ensure the delivery of a quality working system. That means the project was developed in feature increments iteratively using agile software development based on eXtreme Programming (Beck, 2000) and Scrum (Schwaber \& Beedle, 2001). This agile process model has been applied successfully in previous years by the author, and was recommended by several other educators (Alfonso \& Botía, 2005; Chao \& Brown, 2009; Davey \& Parker, 2010).

Prior to the beginning of the semester, the instructor worked with the client to design a semester schedule that contains five time-boxed iterations, which means the length of each iteration is fixed. The first three weeks of the sixteen week semester were used to familiarize the students with software development process and agile methods, followed by five two- to three-week iterations. The semester schedule is summarized in Table 3. 
Table 3: Semester Schedule

\begin{tabular}{|c|c|}
\hline Week(s) & Project Tasks \\
\hline $1-3$ & $\begin{array}{l}\text { - Introduction to software engineering concept and process } \\
\text { - Agile principles, tools, and practices } \\
\text { - } \quad \text { Project overview and teamwork basics }\end{array}$ \\
\hline $4-5$ & $\begin{array}{l}\text { - } \\
\text { - } \quad \text { Initial meeting with client to discuss requirements } \\
\text { - } \quad \text { Project analysis, design, estimation, and planning } \\
\text { - } \quad \text { Develop a project plan including plans for the following four iterations }\end{array}$ \\
\hline $6-8$ & $\begin{array}{l}\text { - Work on } \mathrm{I}_{1} \text { tasks } \\
\text { - } \\
\text { Deliver } \mathrm{I}_{1} \text { (a working system) with accompanying release note and revised project plan }\end{array}$ \\
\hline $9-10$ & $\begin{array}{l}\text { - Work on } \mathrm{I}_{2} \text { tasks } \\
\text { - Deliver } \mathrm{I}_{2} \text { (a working system) with accompanying release note and revised project plan }\end{array}$ \\
\hline $11-12$ & $\begin{array}{l}\text { - Work on } \mathrm{I}_{3} \text { tasks } \\
\text { - } \quad \text { Deliver } \mathrm{I}_{3} \text { (a working system) with accompanying release note and revised project plan }\end{array}$ \\
\hline $13-15$ & $\begin{array}{l}\text { - Work on } \mathrm{I}_{4} \text { tasks } \\
\text { - } \quad \text { Deliver } \mathrm{I}_{4} \text { (the final system) with accompanying release note and revised project plan }\end{array}$ \\
\hline 16 & $\begin{array}{l}\text { - Project retrospective } \\
\text { - Project showcase (presentation and demo to external audience) }\end{array}$ \\
\hline
\end{tabular}

Note that the length variation of the iterations is largely due to university breaks and holidays. Iteration 0 was designed for project preparation and setup including research on technologies, architectural designs, analysis and design, and project planning. Based on their time constraint and skill limitations, the student team had to determine by themselves what requirements and how many requirements they could commit to completing by the end of the semester. At the end of iteration 0 , a project plan including estimation and iteration plans was delivered to the client.

Iterations 1 through 4 each contained a subset of user stories (system features and requirements) to be completed and delivered at the end of the iteration. Also, at the end of each iteration 1 through 4 , there was always a scheduled client meeting for delivery of a working system (with a subset of the requirements), followed by a formal retrospective meeting in which developers asked themselves the following two questions:

1. What went well during the iteration?

2. What could be improved in the next iteration?

By answering the two questions, an action plan was developed. Throughout the semester, class sessions were used mostly for lectures covering other course content and additional skills needed for software development. Students scheduled their own meetings, organizing and working on the project outside of the classroom on their own time.

\section{Future Development}

Due to the time constraint, several user stories originally planned were postponed for future improvement. The user stories, some for instructor user and some for students, are listed in Table 4. 
Table 4: Planned but Unfinished User Stories

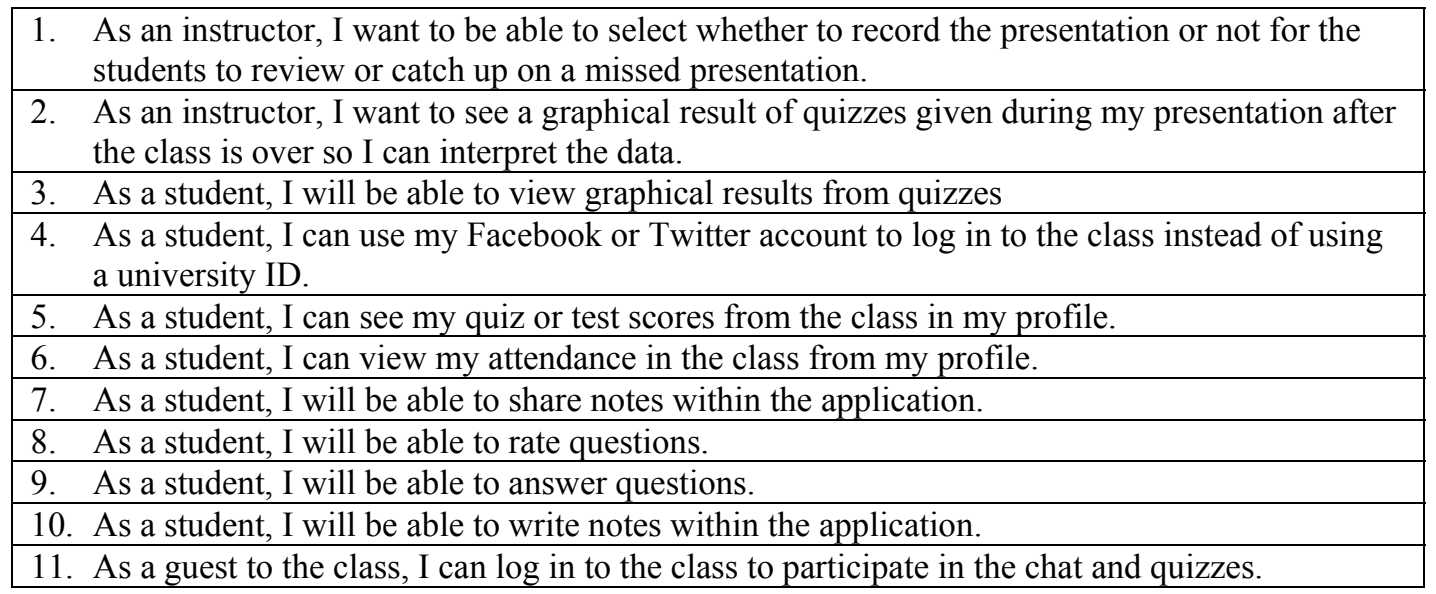

The current version of the system will undergo the first round of live testing in multiple classes during the Spring 2011 semester. Fifteen professors in at least four different programs have made requests to experiment with the system as soon as it is ready. We anticipate that the feedback from the instructors and students running the experiment will provide us with valuable information for future improvements.

\section{Conclusion}

This paper has described an interactive learning system that utilizes social media to enhance lecture delivery and the overall classroom experience. The system was developed by the students in a software development class over the course of a regular semester using agile software methodologies.

Social media technologies are not always appropriate or successful in formal learning settings. Studies indicate that student preferences and expectations for technology use in the classroom differ from the ways in which they use technology on a daily basis for interaction with friends, entertainment, etc. (Waycott, Bennett, Kennedy, Dalgarno \& Gray, 2010). Although the current generation of students spends a great deal of time immersed in social media, some students are unwilling to sacrifice the perceived benefits of face-to-face interactions with the instructor in a traditional classroom setting if offered a technology-based alternative (Smith, Salaway, \& Caruso, 2009).

Thus, it is important that new technologies are integrated into learning and teaching only when driven by pedagogy, rather than technology for technology's sake (McCarthy, 2010). In this case social media technologies are being leveraged in hopes of increasing student engagement in the classroom, improving lecture delivery based on user feedback, and building a community of users - the students and instructor - working toward the common goal of learning. It is an ambitious goal, but even if only a portion is achieved perhaps it will be a first step in improving the learning process for today's digital natives.

\section{References}

Alfonso, M. I., \& Botía, A. (2005). An iterative and agile process model for teaching software engineering. Proceedings of the $18^{\text {th }}$ Conference on Software Engineering Education and Training (CSEET'05), Ottawa, Canada, April 18-20, pp. 9-16. Retrieved December 12, 2010 from http://citeseerx.ist.psu.edu/viewdoc/download?doi=10.1.1.100.9653\&rep=rep1\&type=pdf 
Bargh, J., McKenna, K., \& Fitzsimons, G. (2002). Can you see the real me? Activation and expression of the "true self" on the Internet. Journal of Social Issues, 58(1), 33-48.

Beck, K. (2000). Extreme programming explained: Embrace change. Reading, Massachusetts: AddisonWesley.

Beck, K., \& Fowler, M. (2000). Planning extreme programming. Reading, Massachusetts: AddisonWesley.

Chao, J., \& Brown, J. (2009). Empowering students and the community through agile software development service-learning. The Tenth International Conference on Agile Processes and eXtreme Programming in Software Engineering (XP 2009), Sardinia, Italy, May 26 - 30.

Davey, B., \& Parker, K. R. (2010). Technology in education: An agile systems approach. Proceedings of 2010 Informing Science + Information Technology Education (InSITE) Conference, Cassino, Italy, June 21-24, pp. 297-306. Retrieved February 6, 2011 from http://proceedings.informingscience.org/InSITE2010/InSITE10p297-306Davey785.pdf

Facebook Statistics. (2010). Retrieved December 12, 2010 from http://www.facebook.com/press/info.php?statistics

Hargadon, S. (2009). Educational networking: The important role Web 2.0 will play in education [White paper]. Retrieved December 12, 2010 from http://audio.edtechlive.com/lc/EducationalSocialNetworkingWhitepaper.pdf

Kaplan, A. M., \& Haenlein, M. (2010). Users of the world, unite! The challenges and opportunities of Social Media. Business Horizons, 53(1), 59-68. Retrieved February 5, 2011 from http://openmediart.com/log/pics/sdarticle.pdf

Krause, K., McInnis, C., \& Welle, C. (2003). Out-of-class engagement in undergraduate learning communities: The role and nature of peer interactions. Paper presented at the Association for the Study of Higher Education Conference. Portland, Oregon, USA, November 13-16. Retrieved February 5, 2011 from http://www.eric.ed.gov/ERICWebPortal/contentdelivery/servlet/ERICServlet?accno=ED482146

McCarthy, J. (2008). Utilising Facebook: Immersing Generation-Y students into first year university. Education Research Group of Adelaide Conference 2008, 1(2), 39-49. Retrieved December 13, 2010 from http://digital.library.adelaide.edu.au/dspace/bitstream/2440/49880/1/hdl 49880.pdf

McCarthy, J. (2010). Blended learning environments: Using social networking sites to enhance the first year experience. Australasian Journal of Educational Technology, 26(6), 729-740. Retrieved December 12, 2010 from http://www.ascilite.org.au/ajet/ajet26/mccarthy.html

Parker, K. R. \& Chao, J. (2007). Wiki as a teaching tool. Interdisciplinary Journal of Knowledge and Learning Objects, 3, 57-72. Retrieved December 12, 2010 from http://ijklo.org/Volume3/IJKLOv3p057-072Parker284.pdf

Parker, K. R. \& Chao, J. (2008). Weaving a knowledge web with wikis. In M. D. Lytras, R. D. Tennyson, \& P. Ordóñez de Pablos (Eds.), Knowledge networks: The social software perspective (pp. 28-45). Hershey, Pennsylvania: IGI Global Publishing.

Prensky, M. (2001). Digital natives, digital immigrants. On the Horizon, 9(5), 1-6. Retrieved December 12, 2010 from http://www.albertomattiacci.it/docs/did/Digital_Natives_Digital_Immigrants.pdf

Prensky, M. (2007). How to teach with technology: Keeping both teachers and students comfortable in an era of exponential change. Emerging Technologies for Learning, 2, 40-46. Retrieved December 12, 2010 from http://partners.becta.org.uk/page_documents/research/emerging technologies07_chapter4.pdf

Rao, L. (2010). Twitter seeing 90 million tweets per day, 25 percent contain links. TechCrunch. Retrieved December 12, 2010 from http://techcrunch.com/2010/09/14/twitter-seeing-90-million-tweets-per-day

Schwaber, K. \& Beedle, M. (2001). Agile project management with Scrum. Upper Saddle River, NJ: Prentice Hall. 
Smith, S. D., Salaway, G., \& Caruso, J. (2009). The ECAR study of undergraduate students and information technology, 2009. Boulder, Colorado: EDUCAUSE Center for Applied Research. Retrieved from http://net.educause.edu/ir/library/pdf/ers0906/rs/ERS0906w.pdf

Waycott, J., Bennett, S., Kennedy, G., Dalgarno, B., \& Gray, K. (2010). Digital divides? Student and staff perceptions of information and communication technologies. Computers \& Education, 54(4), 12021211.

Weisgerber, C. (2008, November). Incorporating social media technologies into the communication classroom: How to make the best of blogs, wikis, social bookmarks, and RSS feeds [PowerPoint Slides]. Preconference seminar presented to the Preconference Division of the National Communication Association, San Diego, CA. Retrieved December 12, 2010 from http://www.slideshare.net/corinnew/social-media-in-the-classroom-presentation

Weisgerber, C., \& Butler, S. (2010). Editor's introduction: Special issue on communication pedagogy in the age of social media. Electronic Journal of Communication, 20(1), 1-3. Retrieved December 12, 2010 from http://www.cios.org/www/ejc/v20n12toc.htm

\section{Biographies}

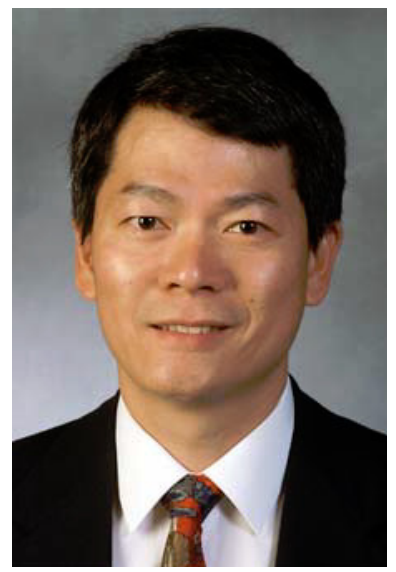

Dr. Joseph T. Chao is an Associate Professor and the Director of the Agile Software Factory in the Department of Computer Science at Bowling Green State University. The Software Factory, which he founded in 2008 with a grant from the Agile Alliance, provides students with service-learning opportunities and real-world project experience in software engineering. Prior to entering academia, Dr. Chao gained more than seven years of industry experience working as Software Engineer, System Analyst, QA Tester, Project Manager as well as Director of Software Development. His research focus is on software engineering with special interests in agile software development, database management systems, web and mobile technologies, and objectoriented analysis and design. Dr. Chao holds an M.S. in Operations Research from Case Western Reserve University and a Ph.D. in Industrial and Systems Engineering from The Ohio State University.

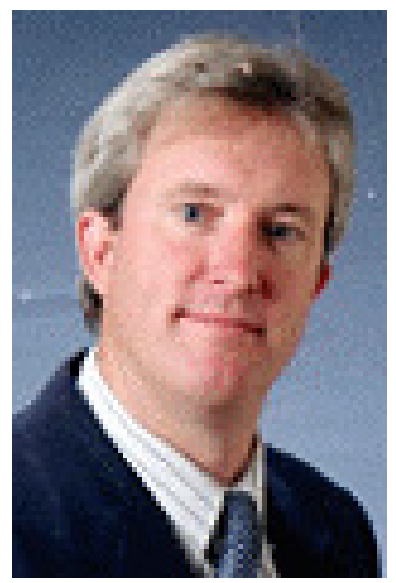

Dr. Kevin R. Parker is a Professor of Computer Information Systems and Computer Science at Idaho State University, having previously held an academic appointment at Saint Louis University. He has taught both computer science and information systems courses over the course of his twenty years in academia. Dr. Parker's research interests include business intelligence, knowledge management, the Semantic Web, and information assurance. He has published in such journals as International Journal of Business Intelligence Research, Education and Information Technologies, Informing Science: the International Journal of an Emerging Transdiscipline, Journal of Information Systems Education, and Communications of the AIS. Dr. Parker's teaching interests include web development technologies, programming languages, data structures, and database management systems. Dr. Parker holds a B.A. in Computer Science from the University of Texas at Austin (1982), an M.S. in Computer Science from Texas Tech University (1991), and a Ph.D. in Management Information Systems from Texas Tech University (1995). 


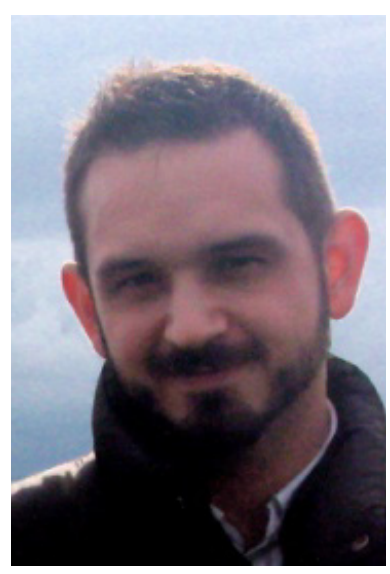

Anthony Fontana is a Learning Technologies Consultant and an Instructor of Art at Bowling Green State University in Ohio. Anthony's pedagogical research involves the importance of divergent methodologies in the classroom, such as "play", integrative teaching strategies, and educational technology applications that optimize learning outcomes by providing channels of content transfer most familiar to the student; something he calls "The Multichronic Classroom". This work focuses on the use of immersive learning environments such as Second Life, social networks such as Facebook, and the way in which students stay engaged, socially motivated, and productive. 